\title{
Calcitonin receptors in GtoPdb v.2021.2
}

\author{
Debbie Hay ${ }^{1}$, David R. Poyner ${ }^{2}$ and Christopher S. Walker ${ }^{1}$
}

1. University of Auckland, New Zealand

2. Aston University, UK

\begin{abstract}
This receptor family comprises a group of receptors for the calcitonin/CGRP family of peptides. The calcitonin (CT), amylin (AMY), calcitonin gene-related peptide (CGRP) and adrenomedullin (AM) receptors (nomenclature as agreed by the NC-IUPHAR Subcommittee on CGRP, AM, AMY, and CT receptors $[131,74,71]$ ) are generated by the genes $C A L C R$ (which codes for the CT receptor) and CALCRL (which codes for the calcitonin receptor-like receptor, CLR, previously known as CRLR). Their function and pharmacology are altered in the presence of RAMPs (receptor activitymodifying proteins), which are single TM domain proteins of $c a .150$ amino acids, identified as a family of three members; RAMP1, RAMP2 and RAMP3. There are splice variants of the CT receptor; these in turn produce variants of the AMY receptor [131], some of which can be potently activated by CGRP. The endogenous agonists are the peptides calcitonin, $\alpha$-CGRP (formerly known as CGRP-I), $\beta$ CGRP (formerly known as CGRP-II), amylin (occasionally called islet-amyloid polypeptide, diabetesassociated polypeptide), adrenomedullin and adrenomedullin 2/intermedin. There are species differences in peptide sequences, particularly for the CTs. CTR-stimulating peptide (CRSP) is another member of the family with selectivity for the CT receptor but it is not expressed in humans [94]. CLR (calcitonin receptor-like receptor) by itself binds no known endogenous ligand, but in the presence of RAMPs it gives receptors for CGRP, adrenomedullin and adrenomedullin 2/intermedin. There are several approved drugs that target this receptor family, such as pramlintide, erenumab, and the "gepant" class of CGRP receptor antagonists.
\end{abstract}

\section{Contents}

This is a citation summary for Calcitonin receptors in the Guide to Pharmacology database (GtoPdb). It exists purely as an adjunct to the database to facilitate the recognition of citations to and from the database by citation analyzers. Readers will almost certainly want to visit the relevant sections of the database which are given here under database links.

GtoPdb is an expert-driven guide to pharmacological targets and the substances that act on them. GtoPdb is a reference work which is most usefully represented as an on-line database. As in any publication this work should be appropriately cited, and the papers it cites should also be recognized. This document provides a citation for the relevant parts of the database, and also provides a reference list for the research cited by those parts. For further details see [28].

Please note that the database version for the citations given in GtoPdb are to the most recent preceding version in which the family or its subfamilies and targets were substantially changed. The links below are to the current version. If you need to consult the cited version, rather than the most recent version, please contact the GtoPdb curators.

\section{Database links}

Calcitonin receptors

https://www.guidetopharmacology.org/GRAC/FamilyDisplayForward?familyId=11

Introduction to Calcitonin receptors

https://www.guidetopharmacology.org/GRAC/FamilyIntroductionForward?familyId=11

Receptors

Complexes

$\mathrm{AMY}_{1}$ receptor

https://www.guidetopharmacology.org/GRAC/ObjectDisplayForward?objectId=44 


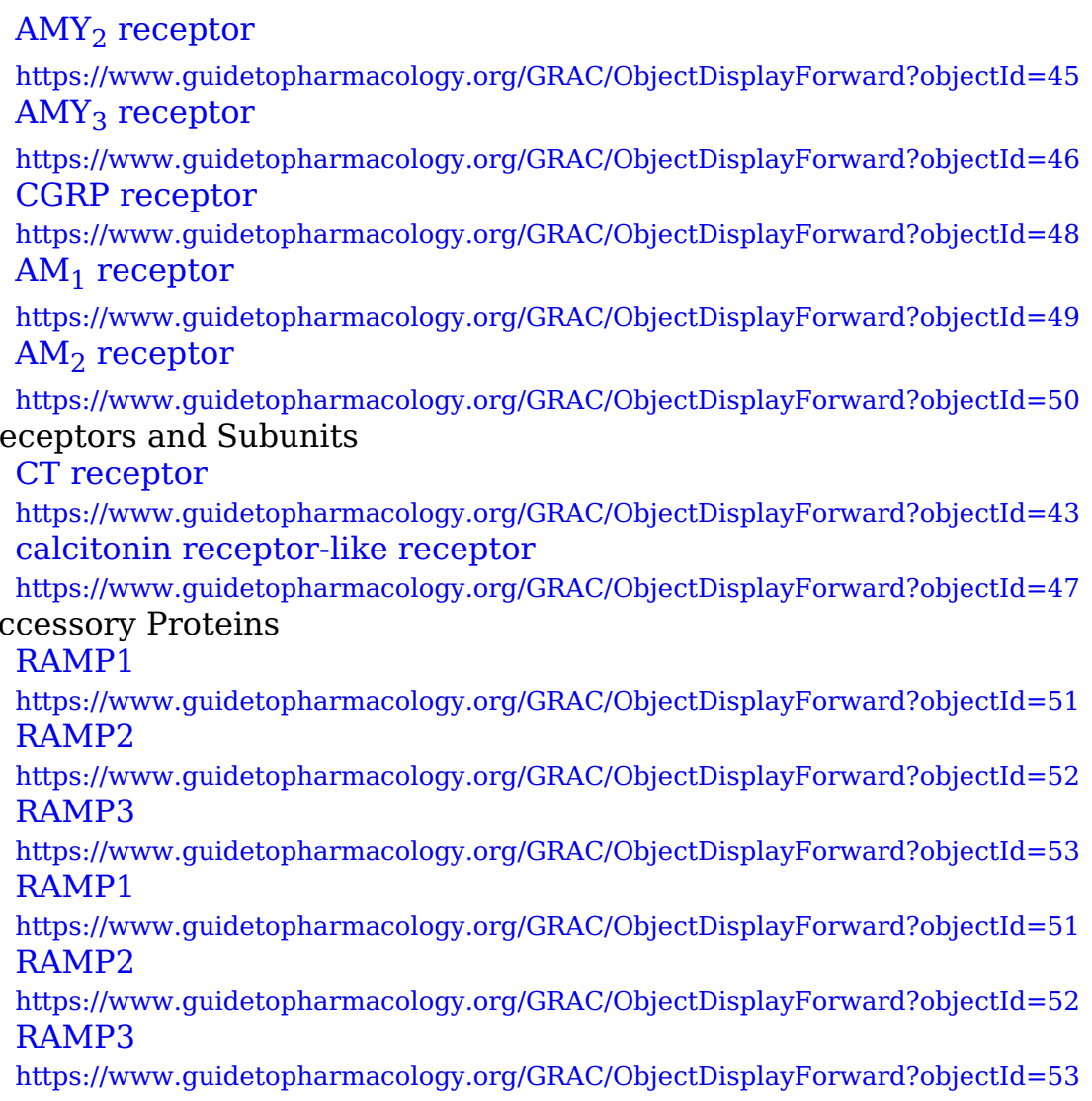

\section{References}

1. Aiyar N, Disa J, Pullen M and Nambi P. (2001) Receptor activity modifying proteins interaction with human and porcine calcitonin receptor-like receptor (CRLR) in HEK-293 cells. Mol Cell Biochem 224: 123-33 [PMID:11693189]

2. Aiyar N, Disa J, Stadel JM and Lysko PG. (1999) Calcitonin gene-related peptide receptor independently stimulates $3^{\prime}, 5^{\prime}$-cyclic adenosine monophosphate and $\mathrm{Ca} 2+$ signaling pathways. Mol Cell Biochem 197: 179-85 [PMID:10485337]

3. Albrandt K, Brady EM, Moore CX, Mull E, Sierzega ME and Beaumont K. (1995) Molecular cloning and functional expression of a third isoform of the human calcitonin receptor and partial characterization of the calcitonin receptor gene. Endocrinology 136: 5377-84 [PMID:7588285]

4. Aldecoa A, Gujer R, Fischer JA and Born W. (2000) Mammalian calcitonin receptor-like receptor/receptor activity modifying protein complexes define calcitonin gene-related peptide and adrenomedullin receptors in Drosophila Schneider 2 cells. FEBS Lett 471: 156-60 [PMID:10767413]

5. Ali N, Yousufzai SY and Abdel-Latif AA. (2000) Activation of particulate guanylate cyclase by adrenomedullin in cultured SV-40 transformed cat iris sphincter smooth muscle (SV-CISM-2) cells. Cell Signal 12: 491-498 [PMID:10989285]

6. Allen MA and Ferguson AV. (1996) In vitro recordings from area postrema neurons demonstrate responsiveness to adrenomedullin. Am J Physiol 270: R920-5 [PMID:8967423]

7. Amara SG, Jonas V, Rosenfeld MG, Ong ES and Evans RM. (1982) Alternative RNA processing in calcitonin gene expression generates mRNAs encoding different polypeptide products. Nature 298: 240-4 [PMID:6283379]

8. Andreis PG, Mazzocchi G, Rebuffat P and Nussdorfer GG. (1997) Effects of adrenomedullin and proadrenomedullin N-terminal 20 peptide on rat zona glomerulosa cells. Life Sci 60: 1693-7 [PMID:9129124]

9. Andreis PG, Neri G, Prayer-Galetti T, Rossi GP, Gottardo G, Malendowicz LK and Nussdorfer GG. (1997) Effects of adrenomedullin on the human adrenal glands: an in vitro study. J Clin Endocrinol Metab 82: 1167-70 [PMID:9100590]

10. Archbold JK, Flanagan JU, Watkins HA, Gingell JJ and Hay DL. (2011) Structural insights into RAMP modification of secretin family G protein-coupled receptors: implications for drug development. Trends Pharmacol Sci 32: 591-600 [PMID:21722971]

11. Armour SL, Foord S, Kenakin T and Chen WJ. (1999) Pharmacological characterization of receptor-activity-modifying proteins (RAMPs) and the human calcitonin receptor. J Pharmacol Toxicol Methods 42: 217-24 [PMID:11033437]

12. Arulmani U, Schuijt MP, Heiligers JP, Willems EW, Villalón CM and Saxena PR. (2004) Effects of 
the calcitonin gene-related peptide (CGRP) receptor antagonist BIBN4096BS on alpha-CGRPinduced regional haemodynamic changes in anaesthetised rats. Basic Clin Pharmacol Toxicol 94: 291-7 [PMID:15228501]

13. Avgoustou P. et al.. (2020) Discovery of a First-in-Class Potent Small Molecule Antagonist against the Adrenomedullin-2 Receptor ACS Pharmacol Transl Sci

14. Bailey RJ and Hay DL. (2006) Pharmacology of the human CGRP1 receptor in Cos 7 cells. Peptides 27: 1367-75 [PMID:16375989]

15. Bailey RJ, Walker CS, Ferner AH, Loomes KM, Prijic G, Halim A, Whiting L, Phillips AR and Hay DL. (2012) Pharmacological characterization of rat amylin receptors: implications for the identification of amylin receptor subtypes. Br J Pharmacol 166: 151-67 [PMID:22014233]

16. Barrick CJ, Lenhart PM, Dackor RT, Nagle E and Caron KM. (2012) Loss of receptor activitymodifying protein 3 exacerbates cardiac hypertrophy and transition to heart failure in a sexdependent manner. J Mol Cell Cardiol 52: 165-74 [PMID:22100352]

17. Becskei C, Riediger T, Zünd D, Wookey P and Lutz TA. (2004) Immunohistochemical mapping of calcitonin receptors in the adult rat brain. Brain Res 1030: 221-33 [PMID:15571671]

18. Bell D and McDermott BJ. (1994) Calcitonin gene-related peptide stimulates a positive contractile response in rat ventricular cardiomyocytes. J Cardiovasc Pharmacol 23: 1011-21 [PMID:7523774]

19. Bell IM and Fraley ME. (2012) Piperidinone carboxamide azaindane CGRP receptor antagonists. Patent number: US20120122911.

20. Bell IM, Fraley ME, Gallicchio SN, Ginnetti A, Mitchell HJ, Paone DV, Staas DD, Stevenson HE, Wang C and Zartman CB. (2012) Piperidinone carboxamide azaindane cgrp receptor antagonists Patent number: WO2012064910A1.

21. Bhogal R, Smith DM and Bloom SR. (1992) Investigation and characterization of binding sites for islet amyloid polypeptide in rat membranes. Endocrinology 130: 906-13 [PMID:1310282]

22. Bomberger JM, Parameswaran N, Hall CS, Aiyar N and Spielman WS. (2005) Novel function for receptor activity-modifying proteins (RAMPs) in post-endocytic receptor trafficking. J Biol Chem 280: 9297-307 [PMID:15613468]

23. Booe JM, Walker CS, Barwell J, Kuteyi G, Simms J, Jamaluddin MA, Warner ML, Bill RM, Harris PW and Brimble MA et al.. (2015) Structural Basis for Receptor Activity-Modifying ProteinDependent Selective Peptide Recognition by a G Protein-Coupled Receptor. Mol Cell 58: 104052 [PMID:25982113]

24. Brain SD and Grant AD. (2004) Vascular actions of calcitonin gene-related peptide and adrenomedullin. Physiol Rev 84: 903-34 [PMID:15269340]

25. Brain SD, Poyner DR and Hill RG. (2002) CGRP receptors: a headache to study, but will antagonists prove therapeutic in migraine? Trends Pharmacol Sci 23: 51-3 [PMID:11830255]

26. Bucknell SJ, Ator MA, Brown AJH, Brown J, Cansfield AD, Cansfield JE, Christopher JA, Congreve M, Cseke G and Deflorian F et al.. (2020) Structure-Based Drug Discovery of $N-((R)-3-$ (7-Methyl-1H-indazol-5-yl)-1-oxo-1-(( $S$ )-1-oxo-3-(piperidin-4-yl)-1-(4-(pyridin-4-yl)piperazin-1yl)propan-2-yl)amino)propan-2-yl)-2'-oxo-1',2'-dihydrospiro[piperidine-4,4'-pyrido[2,3-d] [1,3]oxazine]-1-carboxamide (HTL22562): A Calcitonin Gene-Related Peptide Receptor Antagonist for Acute Treatment of Migraine. J Med Chem 63: 7906-7920 [PMID:32558564]

27. Bullock CM, Wookey P, Bennett A, Mobasheri A, Dickerson I and Kelly S. (2014) Peripheral calcitonin gene-related peptide receptor activation and mechanical sensitization of the joint in rat models of osteoarthritis pain. Arthritis Rheumatol 66: 2188-200 [PMID:24719311]

28. Buneman P, Christie G, Davies JA, Dimitrellou R, Harding SD, Pawson AJ, Sharman JL and Wu Y. (2020) Why data citation isn't working, and what to do about it Database 2020 [PMID:32367113]

29. Bühlmann N, Leuthäuser K, Muff R, Fischer JA and Born W. (1999) A receptor activity modifying protein (RAMP)2-dependent adrenomedullin receptor is a calcitonin gene-related peptide receptor when coexpressed with human RAMP1. Endocrinology 140: 2883-90 [PMID:10342881]

30. Caron KM and Smithies O. (2001) Extreme hydrops fetalis and cardiovascular abnormalities in mice lacking a functional Adrenomedullin gene. Proc Natl Acad Sci USA 98: 615-9 [PMID:11149956]

31. Chait A, Suaudeau C and De Beaurepaire R. (1995) Extensive brain mapping of calcitonininduced anorexia. Brain Res Bull 36: 467-472 [PMID:7712209]

32. Chambers TJ and Magnus CJ. (1982) Calcitonin alters behaviour of isolated osteoclasts. J Pathol 136: 27-39 [PMID:7057295]

33. Champion HC, Bivalacqua TJ, Pierce RL, Murphy WA, Coy DH, Hyman AL and Kadowitz PJ. (2003) Responses to human CGRP, ADM, and PAMP in human thymic arteries. Am J Physiol Regul Integr Comp Physiol 284: R531-7 [PMID:12529288]

34. Chaturvedula PV, Mercer SE, Pin SS, Thalody G, Xu C, Conway CM, Keavy D, Signor L, Cantor GH and Mathias N et al.. (2013) Discovery of (R)-N-(3-(7-methyl-1H-indazol-5-yl)-1-(4-(1methylpiperidin-4-yl)-1-oxopropan-2-yl)-4-(2-oxo-1,2-dihydroquinolin-3-yl)piperidine-1carboxamide (BMS-742413): a potent human CGRP antagonist with superior safety profile for 
the treatment of migraine through intranasal delivery. Bioorg Med Chem Lett 23: 3157-61 [PMID:23632269]

35. Chausmer A, Stuart C and Stevens M. (1980) Identification of testicular cell plasma membrane receptors for calcitonin. J Lab Clin Med 96: 933-8 [PMID:6252270]

36. Chausmer AB, Stevens MD and Severn C. (1982) Autoradiographic evidence for a calcitonin receptor on testicular Leydig cells. Science 216: 735-6 [PMID:6281881]

37. Chiba T, Yamaguchi A, Yamatani T, Nakamura A, Morishita T, Inui T, Fukase M, Noda T and Fujita T. (1989) Calcitonin gene-related peptide receptor antagonist human CGRP-(8-37). Am J Physiol 256: E331-5 [PMID:2537579]

38. Christopoulos G, Perry KJ, Morfis M, Tilakaratne N, Gao Y, Fraser NJ, Main MJ, Foord SM and Sexton PM. (1999) Multiple amylin receptors arise from receptor activity-modifying protein interaction with the calcitonin receptor gene product. Mol Pharmacol 56: 235-42 [PMID:10385705]

39. Clarke MV, Russell PK, Findlay DM, Sastra S, Anderson PH, Skinner JP, Atkins GJ, Zajac JD and Davey RA. (2015) A Role for the Calcitonin Receptor to Limit Bone Loss During Lactation in Female Mice by Inhibiting Osteocytic Osteolysis. Endocrinology 156: 3203-14 [PMID:26135836]

40. Cohen DP, Nussenzveig DR and Gershengorn MC. (1996) Iodocalcitonin binds to human calcitonin receptors with higher affinity than calcitonin. Endocrinology 137: 4507-10 [PMID:8828514]

41. Cooper GJ, Leighton B, Dimitriadis GD, Parry-Billings M, Kowalchuk JM, Howland K, Rothbard JB, Willis AC and Reid KB. (1988) Amylin found in amyloid deposits in human type 2 diabetes mellitus may be a hormone that regulates glycogen metabolism in skeletal muscle. Proc Natl Acad Sci USA 85: 7763-6 [PMID:3051005]

42. Cooper GJ, Willis AC, Clark A, Turner RC, Sim RB and Reid KB. (1987) Purification and characterization of a peptide from amyloid-rich pancreases of type 2 diabetic patients. Proc Natl Acad Sci USA 84: 8628-32 [PMID:3317417]

43. Cornish J, Callon KE, Lin CQ, Xiao CL, Gamble GD, Cooper GJ and Reid IR. (1999) Comparison of the effects of calcitonin gene-related peptide and amylin on osteoblasts. J Bone Miner Res 14: 1302-9 [PMID:10457262]

44. Dackor R, Fritz-Six K, Smithies O and Caron K. (2007) Receptor activity-modifying proteins 2 and 3 have distinct physiological functions from embryogenesis to old age. J Biol Chem 282: 18094-9 [PMID:17470425]

45. Dackor RT, Fritz-Six K, Dunworth WP, Gibbons CL, Smithies O and Caron KM. (2006) Hydrops fetalis, cardiovascular defects, and embryonic lethality in mice lacking the calcitonin receptorlike receptor gene. Mol Cell Biol 26: 2511-8 [PMID:16537897]

46. Dacquin R, Davey RA, Laplace C, Levasseur R, Morris HA, Goldring SR, Gebre-Medhin S, Galson DL, Zajac JD and Karsenty G. (2004) Amylin inhibits bone resorption while the calcitonin receptor controls bone formation in vivo. J Cell Biol 164: 509-14 [PMID:14970190]

47. Davey RA, Turner A, McManus JF, Chiu WS, Tjahyono F, Moore AJ, Atkins GJ, Anderson PH, Ma C, Glatt V, Maclean HE, Vincent C, Bouxsein M, Morris HA, Findlay DM and Zajac JD. (2008) The Calcitonin Receptor Plays a Physiological Role to Protect Against Hypercalcemia in Mice. $J$ Bone Miner Res 8: 1182-1193 [PMID:18627265]

48. Dennis T, Fournier A, St Pierre S and Quirion R. (1989) Structure-activity profile of calcitonin gene-related peptide in peripheral and brain tissues. Evidence for receptor multiplicity. $J$ Pharmacol Exp Ther 251: 718-25 [PMID:2553933]

49. Devesa I, Ferrándiz-Huertas C, Mathivanan S, Wolf C, Luján R, Changeux JP and Ferrer-Montiel A. (2014) $\alpha$ CGRP is essential for algesic exocytotic mobilization of TRPV1 channels in peptidergic nociceptors. Proc Natl Acad Sci USA 111: 18345-50 [PMID:25489075]

50. Dong M, Cox RF and Miller LJ. (2009) Juxtamembranous region of the amino terminus of the family B G protein-coupled calcitonin receptor plays a critical role in small-molecule agonist action. J Biol Chem 284: 21839-47 [PMID:19447889]

51. Doods H, Hallermayer G, Wu D, Entzeroth M, Rudolf K, Engel W and Eberlein W. (2000) Pharmacological profile of BIBN4096BS, the first selective small molecule CGRP antagonist. $\mathrm{Br} \mathrm{J}$ Pharmacol 129: 420-3 [PMID:10711339]

52. Edvinsson L, Gulbenkian S, Barroso CP, Cunha e Sá M, Polak JM, Mortensen A, Jørgensen L and Jansen-Olesen I. (1998) Innervation of the human middle meningeal artery: immunohistochemistry, ultrastructure, and role of endothelium for vasomotility. Peptides 19: 1213-25 [PMID:9786171]

53. Edvinsson L, Sams A, Jansen-Olesen I, Tajti J, Kane SA, Rutledge RZ, Koblan KS, Hill RG and Longmore J. (2001) Characterisation of the effects of a non-peptide CGRP receptor antagonist in SK-N-MC cells and isolated human cerebral arteries. Eur J Pharmacol 415: 39-44 [PMID:11245850]

54. Evans BN, Rosenblatt MI, Mnayer LO, Oliver KR and Dickerson IM. (2000) CGRP-RCP, a novel protein required for signal transduction at calcitonin gene-related peptide and adrenomedullin receptors. J Biol Chem 275: 31438-43 [PMID:10903324] 
55. Felsenfeld AJ and Levine BS. (2015) Calcitonin, the forgotten hormone: does it deserve to be forgotten? Clin Kidney J 8: 180-7 [PMID:25815174]

56. Fraser NJ, Wise A, Brown J, McLatchie LM, Main MJ and Foord SM. (1999) The amino terminus of receptor activity modifying proteins is a critical determinant of glycosylation state and ligand binding of calcitonin receptor-like receptor. Mol Pharmacol 55: 1054-1059 [PMID:10347248]

57. Fritz-Six KL, Dunworth WP, Li M and Caron KM. (2008) Adrenomedullin signaling is necessary for murine lymphatic vascular development. J Clin Invest 118: 40-50 [PMID:18097475]

58. Galvin RJ, Bryan P, Venugopalan M, Smith DP and Thomas JE. (1998) Calcitonin responsiveness and receptor expression in porcine and murine osteoclasts: a comparative study. Bone 23: 23340 [PMID:9737345]

59. Gebre-Medhin S, Mulder H, Pekny M, Westermark G, Törnell J, Westermark P, Sundler F, Ahrén B and Betsholtz C. (1998) Increased insulin secretion and glucose tolerance in mice lacking islet amyloid polypeptide (amylin). Biochem Biophys Res Commun 250: 271-7 [PMID:9753619]

60. Gingell JJ, Burns ER and Hay DL. (2014) Activity of pramlintide, rat and human amylin but not Aß1-42 at human amylin receptors. Endocrinology 155: 21-6 [PMID:24169554]

61. Gorn AH, Lin HY, Yamin M, Auron PE, Flannery MR, Tapp DR, Manning CA, Lodish HF, Krane SM and Goldring SR. (1992) Cloning, characterization, and expression of a human calcitonin receptor from an ovarian carcinoma cell line. J Clin Invest 90: 1726-35 [PMID:1331173]

62. Gorn AH, Rudolph SM, Flannery MR, Morton CC, Weremowicz S, Wang TZ, Krane SM and Goldring SR. (1995) Expression of two human skeletal calcitonin receptor isoforms cloned from a giant cell tumor of bone. The first intracellular domain modulates ligand binding and signal transduction. J Clin Invest 95: 2680-2691 [PMID:7769107]

63. Gydesen S, Andreassen KV, Hjuler ST, Christensen JM, Karsdal MA and Henriksen K. (2016) KBP-088, a novel DACRA with prolonged receptor activation, is superior to davalintide in terms of efficacy on body weight. Am J Physiol Endocrinol Metab 310: E821-7 [PMID:26908506]

64. Han SP, Naes L and Westfall TC. (1990) Calcitonin gene-related peptide is the endogenous mediator of nonadrenergic-noncholinergic vasodilation in rat mesentery.J Pharmacol Exp Ther 255: 423-8 [PMID:2243334]

65. Hay DL. (2019) CGRP Receptor Biology: Is There More Than One Receptor? Handb Exp Pharmacol 255: 13-22 [PMID:29797087]

66. Hay DL. (2007) What makes a CGRP2 receptor? Clin Exp Pharmacol Physiol 34: 963-71 [PMID:17714080]

67. Hay DL, Chen S, Lutz TA, Parkes DG and Roth JD. (2015) Amylin: Pharmacology, Physiology, and Clinical Potential. Pharmacol Rev 67: 564-600 [PMID:26071095]

68. Hay DL, Christopoulos G, Christopoulos A, Poyner DR and Sexton PM. (2005) Pharmacological discrimination of calcitonin receptor: receptor activity-modifying protein complexes. $\mathrm{Mol}$ Pharmacol 67: 1655-65 [PMID:15692146]

69. Hay DL, Christopoulos G, Christopoulos A and Sexton PM. (2006) Determinants of 1piperidinecarboxamide, N-[2-[[5-amino-l-[[4-(4-pyridinyl)-l-piperazinyl]carbonyl]pentyl]amino]-1[(3,5-dibromo-4-hydroxyphenyl)methyl]-2-oxoethyl]-4-(1,4-dihydro-2-oxo-3(2H)-quinazolinyl) (BIBN4096BS) affinity for calcitonin gene-related peptide and amylin receptors--the role of receptor activity modifying protein 1. Mol Pharmacol 70: 1984-1991 [PMID:16959943]

70. Hay DL, Conner AC, Howitt SG, Takhshid MA, Simms J, Mahmoud K and Poyner DR. (2004) The pharmacology of CGRP-responsive receptors in cultured and transfected cells. Peptides 25: 2019-2026 [PMID:15501536]

71. Hay DL, Garelja ML, Poyner DR and Walker CS. (2018) Update on the pharmacology of calcitonin/CGRP family of peptides: IUPHAR Review 25. Br J Pharmacol 175: 3-17 [PMID:29059473]

72. Hay DL, Howitt SG, Conner AC, Schindler M, Smith DM and Poyner DR. (2003) CL/RAMP2 and CL/RAMP3 produce pharmacologically distinct adrenomedullin receptors: a comparison of effects of adrenomedullin22-52, CGRP8-37 and BIBN4096BS. Br J Pharmacol 140: 477-86 [PMID:12970090]

73. Hay DL and Pioszak AA. (2016) Receptor Activity-Modifying Proteins (RAMPs): New Insights and Roles. Annu Rev Pharmacol Toxicol 56: 469-87 [PMID:26514202]

74. Hay DL, Poyner DR, Quirion R and International Union of Pharmacology. (2008) International Union of Pharmacology. LXIX. Status of the calcitonin gene-related peptide subtype 2 receptor. Pharmacol Rev 60: 143-5 [PMID:18552275]

75. Hay DL, Poyner DR and Sexton PM. (2006) GPCR modulation by RAMPs. Pharmacol Ther 109: 173-97 [PMID:16111761]

76. Haynes JM and Cooper ME. (1995) Adrenomedullin and calcitonin gene-related peptide in the rat isolated kidney and in the anaesthetised rat: in vitro and in vivo effects. Eur J Pharmacol 280: 91-4 [PMID:7498258]

77. Hilton JM, Dowton M, Houssami S and Sexton PM. (2000) Identification of key components in the irreversibility of salmon calcitonin binding to calcitonin receptors. J Endocrinol 166: 213-26 [PMID:10856900] 
78. Hinson JP, Kapas S and Smith DM. (2000) Adrenomedullin, a multifunctional regulatory peptide. Endocr Rev 21: 138-67 [PMID:10782362]

79. Hoare SR. (2005) Mechanisms of peptide and nonpeptide ligand binding to Class B G-proteincoupled receptors. Drug Discov Today 10: 417-27 [PMID:15808821]

80. Hong Y, Hay DL, Quirion R and Poyner DR. (2012) The pharmacology of adrenomedullin 2/intermedin. Br J Pharmacol 166: 110-20 [PMID:21658025]

81. Hoshiya H, Meguro M, Kashiwagi A, Okita C and Oshimura M. (2003) Calcr, a brain-specific imprinted mouse calcitonin receptor gene in the imprinted cluster of the proximal region of chromosome 6. J Hum Genet 48: 208-11 [PMID:12730726]

82. Husmann K, Born W, Fischer JA and Muff R. (2003) Three receptor-activity-modifying proteins define calcitonin gene-related peptide or adrenomedullin selectivity of the mouse calcitonin-like receptor in COS-7 cells. Biochem Pharmacol 66: 2107-15 [PMID:14609735]

83. Husmann K, Sexton PM, Fischer JA and Born W. (2000) Mouse receptor-activity-modifying proteins 1, -2 and -3: amino acid sequence, expression and function. Mol Cell Endocrinol 162: 35-43 [PMID:10854696]

84. Ichikawa I and Brenner BM. (1976) Of unglazed pottery and glomerular sieving. Kidney Int 10: 264-7 [PMID:787620]

85. Ichikawa-Shindo Y, Sakurai T, Kamiyoshi A, Kawate H, Iinuma N, Yoshizawa T, Koyama T, Fukuchi J, Iimuro S and Moriyama N et al.. (2008) The GPCR modulator protein RAMP2 is essential for angiogenesis and vascular integrity. J Clin Invest 118: 29-39 [PMID:18097473]

86. Igarashi K, Sakurai T, Kamiyoshi A, Ichikawa-Shindo Y, Kawate H, Yamauchi A, Toriyama Y, Tanaka M, Liu T and Xian X et al.. (2014) Pathophysiological roles of adrenomedullin-RAMP2 system in acute and chronic cerebral ischemia. Peptides 62: 21-31 [PMID:25252154]

87. Joshi P, Anderson C, Binch H, Hadida S, Yoo S, Bergeron D, Decker C, terHaar E, Moore J and Garcia-Guzman M et al.. (2014) Identification of potent CNS-penetrant thiazolidinones as novel CGRP receptor antagonists. Bioorg Med Chem Lett 24: 845-9 [PMID:24405707]

88. Jusek G, Reim D, Tsujikawa K and Holzmann B. (2012) Deficiency of the CGRP receptor component RAMP1 attenuates immunosuppression during the early phase of septic peritonitis. Immunobiology 217: 761-7 [PMID:22656887]

89. Kahn ML. (2008) Blood is thicker than lymph. J Clin Invest 118: 23-6 [PMID:18097477]

90. Kano H, Kohno M, Yasunari K, Yokokawa K, Horio T, Ikeda M, Minami M, Hanehira T, Takeda T and Yoshikawa J. (1996) Adrenomedullin as a novel antiproliferative factor of vascular smooth muscle cells. J Hypertens 14: 209-13 [PMID:8728298]

91. Kapoor K, Arulmani U, Heiligers JP, Garrelds IM, Willems EW, Doods H, Villalón CM and Saxena PR. (2003) Effects of the CGRP receptor antagonist BIBN4096BS on capsaicin-induced carotid haemodynamic changes in anaesthetised pigs. Br J Pharmacol 140: 329-38 [PMID:12970078]

92. Kapoor K, Arulmani U, Heiligers JP, Willems EW, Doods H, Villalón CM and Saxena PR. (2003) Effects of BIBN4096BS on cardiac output distribution and on CGRP-induced carotid haemodynamic responses in the pig. Eur J Pharmacol 475: 69-77 [PMID:12954361]

93. Katafuchi T, Hamano K, Kikumoto K and Minamino N. (2003) Identification of second and third calcitonin receptor-stimulating peptides in porcine brain. Biochem Biophys Res Commun 308: 445-51 [PMID:12914769]

94. Katafuchi T, Kikumoto K, Hamano K, Kangawa K, Matsuo H and Minamino N. (2003) Calcitonin receptor-stimulating peptide, a new member of the calcitonin gene-related peptide family. Its isolation from porcine brain, structure, tissue distribution, and biological activity. J Biol Chem 278: 12046-54 [PMID:12556539]

95. Kiriyama Y, Tsuchiya H, Murakami T, Satoh K and Tokumitsu Y. (2001) Calcitonin induces IL-6 production via both PKA and PKC pathways in the pituitary folliculo-stellate cell line. Endocrinology 142: 3563-9 [PMID:11459804]

96. Kitamura K, Kangawa K, Kawamoto M, Ichiki Y, Nakamura S, Matsuo H and Eto T. (1993) Adrenomedullin: a novel hypotensive peptide isolated from human pheochromocytoma. Biochem Biophys Res Commun 192: 553-60 [PMID:8387282]

97. Kurashige C, Hosono K, Matsuda H, Tsujikawa K, Okamoto H and Majima M. (2014) Roles of receptor activity-modifying protein 1 in angiogenesis and lymphangiogenesis during skin wound healing in mice. FASEB J 28: 1237-47 [PMID:24308973]

98. Kusano S, Kukimoto-Niino M, Akasaka R, Toyama M, Terada T, Shirouzu M, Shindo T and Yokoyama S. (2008) Crystal structure of the human receptor activity-modifying protein 1 extracellular domain. Protein Sci 17: 1907-14 [PMID:18725456]

99. Kusano S, Kukimoto-Niino M, Hino N, Ohsawa N, Okuda K, Sakamoto K, Shirouzu M, Shindo T and Yokoyama S. (2012) Structural basis for extracellular interactions between calcitonin receptor-like receptor and receptor activity-modifying protein 2 for adrenomedullin-specific binding. Protein Sci 21: 199-210 [PMID:22102369]

100. Kuwasako K, Cao YN, Nagoshi Y, Tsuruda T, Kitamura K and Eto T. (2004) Characterization of the human calcitonin gene-related peptide receptor subtypes associated with receptor activitymodifying proteins. Mol Pharmacol 65: 207-13 [PMID:14722252] 
101. Kuwasako K, Kitamura K, Nagoshi Y and Eto T. (2003) Novel calcitonin-(8-32)-sensitive adrenomedullin receptors derived from co-expression of calcitonin receptor with receptor activity-modifying proteins. Biochem Biophys Res Commun 301: 460-4 [PMID:12565884]

102. Leighton B and Cooper GJ. (1988) Pancreatic amylin and calcitonin gene-related peptide cause resistance to insulin in skeletal muscle in vitro. Nature 335: 632-5 [PMID:3050530]

103. Leuthauser K, Gujer R, Aldecoa A, McKinney RA, Muff R, Fischer JA and Born W. (2000) Receptor-activity-modifying protein 1 forms heterodimers with two G-protein-coupled receptors to define ligand recognition. Biochem J 351: 347-351 [PMID:11023820]

104. Lin HY, Harris TL, Flannery MS, Aruffo A, Kaji EH, Gorn A, Kolakowski Jr LF, Lodish HF and Goldring SR. (1991) Expression cloning of an adenylate cyclase-coupled calcitonin receptor. Science 254: 1022-4 [PMID:1658940]

105. Luo G, Chen L, Conway CM, Denton R, Keavy D, Signor L, Kostich W, Lentz KA, Santone KS and Schartman R et al.. (2012) Discovery of (5S,6S,9R)-5-amino-6-(2,3-difluorophenyl)-6, 7,8,9tetrahydro-5H-cyclohepta[b]pyridin-9-yl 4-(2-oxo-2,3-dihydro-1H-imidazo[4,5-b]pyridin-1yl)piperidine-1-carboxylate (BMS-927711): an oral calcitonin gene-related peptide (CGRP) antagonist in clinical trials for treating migraine. J Med Chem 55: 10644-51 [PMID:23153230]

106. Lutz TA. (2006) Amylinergic control of food intake. Physiol Behav 89: 465-71 [PMID:16697020]

107. Main MJ, Brown J, Brown S, Fraser NJ and Foord SM. (1998) The CGRP receptor can couple via pertussis toxin sensitive and insensitive G proteins. FEBS Lett 441: 6-10 [PMID:9877154]

108. Mallee JJ, Salvatore CA, LeBourdelles B, Oliver KR, Longmore J, Koblan KS and Kane SA. (2002) Receptor activity-modifying protein 1 determines the species selectivity of non-peptide CGRP receptor antagonists. J Biol Chem 277: 14294-8 [PMID:11847213]

109. Martínez V, Cuttitta F and Taché Y. (1997) Central action of adrenomedullin to inhibit gastric emptying in rats. Endocrinology 138: 3749-55 [PMID:9275061]

110. Masi L, Becherini L, Gennari L, Colli E, Mansani R, Falchetti A, Cepollaro C, Gonnelli S, Tanini A and Brandi ML. (1998) Allelic variants of human calcitonin receptor: distribution and association with bone mass in postmenopausal Italian women. Biochem Biophys Res Commun 245: 622-6 [PMID:9571205]

111. McLatchie LM, Fraser NJ, Main MJ, Wise A, Brown J, Thompson N, Solari R, Lee MG and Foord SM. (1998) RAMPs regulate the transport and ligand specificity of the calcitonin-receptor-like receptor. Nature 393: 333-9 [PMID:9620797]

112. Mercer SE, Chaturvedula PV, Conway CM, Cook DA, Davis CD, Pin SS, Macci R, Schartman R, Signor LJ and Widmann KA et al.. (2021) Azepino-indazoles as calcitonin gene-related peptide (CGRP) receptor antagonists. Bioorg Med Chem Lett 31: 127624 [PMID:33096162]

113. Mikami N, Watanabe K, Hashimoto N, Miyagi Y, Sueda K, Fukada S, Yamamoto H and Tsujikawa K. (2012) Calcitonin gene-related peptide enhances experimental autoimmune encephalomyelitis by promoting Th17-cell functions. Int Immunol 24: 681-91 [PMID:22843730]

114. Mitsikostas DD and Rapoport AM. (2015) New players in the preventive treatment of migraine. BMC Med 13: 279 [PMID:26555040]

115. Mogil JS, Miermeister F, Seifert F, Strasburg K, Zimmermann K, Reinold H, Austin JS, Bernardini N, Chesler EJ and Hofmann HA et al.. (2005) Variable sensitivity to noxious heat is mediated by differential expression of the CGRP gene. Proc Natl Acad Sci USA 102: 12938-43 [PMID:16118273]

116. Moore EL and Salvatore CA. (2012) Targeting a family B GPCR/RAMP receptor complex: CGRP receptor antagonists and migraine. Br J Pharmacol 166: 66-78 [PMID:21871019]

117. Morfis M, Tilakaratne N, Furness SG, Christopoulos G, Werry TD, Christopoulos A and Sexton PM. (2008) Receptor activity-modifying proteins differentially modulate the G protein-coupling efficiency of amylin receptors. Endocrinology 149: 5423-31 [PMID:18599553]

118. Muff R, Bühlmann N, Fischer JA and Born W. (1999) An amylin receptor is revealed following cotransfection of a calcitonin receptor with receptor activity modifying proteins-1 or -3.

Endocrinology 140: 2924-7 [PMID:10342886]

119. Mulderry PK, Ghatei MA, Spokes RA, Jones PM, Pierson AM, Hamid QA, Kanse S, Amara SG, Burrin JM and Legon S et al.. (1988) Differential expression of alpha-CGRP and beta-CGRP by primary sensory neurons and enteric autonomic neurons of the rat. Neuroscience 25: 195-205 [PMID:2839796]

120. Nakamura M, Zhang ZQ, Shan L, Hisa T, Sasaki M, Tsukino R, Yokoi T, Kaname A and Kakudo K. (1997) Allelic variants of human calcitonin receptor in the Japanese population. Hum Genet 99: 38-41 [PMID:9003491]

121. Nakamuta H, Fukuda Y, Koida M, Fujii N, Otaka A, Funakoshi S, Yajima H, Mitsuyasu N and Orlowski RC. (1986) Binding sites of calcitonin gene-related peptide (CGRP): abundant occurrence in visceral organs. Jpn J Pharmacol 42: 175-80 [PMID:3025489]

122. Nishimatsu H, Suzuki E, Nagata D, Moriyama N, Satonaka H, Walsh K, Sata M, Kangawa K, Matsuo H and Goto A et al.. (2001) Adrenomedullin induces endothelium-dependent vasorelaxation via the phosphatidylinositol 3-kinase/Akt-dependent pathway in rat aorta. Circ Res 89: 63-70 [PMID:11440979] 
123. Nodin C, Vauquelin G and von Mentzer B. (2005) Cys2,7EtalphaCGRP is a potent agonist for CGRP1 receptors in SK-N-MC cells. Biochem Pharmacol 69: 1235-40 [PMID:15794944]

124. Offermanns S, Iida-Klein A, Segre GV and Simon MI. (1996) G alpha q family members couple parathyroid hormone (PTH)/PTH-related peptide and calcitonin receptors to phospholipase C in COS-7 cells. Mol Endocrinol 10: 566-74 [PMID:8732687]

125. Oliver KR, Kane SA, Salvatore CA, Mallee JJ, Kinsey AM, Koblan KS, Keyvan-Fouladi N, Heavens RP, Wainwright A and Jacobson M et al.. (2001) Cloning, characterization and central nervous system distribution of receptor activity modifying proteins in the rat. Eur J Neurosci 14: 618-28 [PMID:11556887]

126. Owji AA, Smith DM, Coppock HA, Morgan DG, Bhogal R, Ghatei MA and Bloom SR. (1995) An abundant and specific binding site for the novel vasodilator adrenomedullin in the rat.

Endocrinology 136: 2127-34 [PMID:7720662]

127. Parameswaran N, Disa J, Spielman WS, Brooks DP, Nambi P and Aiyar N. (2000) Activation of multiple mitogen-activated protein kinases by recombinant calcitonin gene-related peptide receptor. Eur J Pharmacol 389: 125-30 [PMID:10688975]

128. Petersen KA, Birk S, Lassen LH, Kruuse C, Jonassen O, Lesko L and Olesen J. (2005) The CGRPantagonist, BIBN4096BS does not affect cerebral or systemic haemodynamics in healthy volunteers. Cephalalgia 25: 139-47 [PMID:15658951]

129. Pham V, Wade JD, Purdue BW and Sexton PM. (2004) Spatial proximity between a photolabile residue in position 19 of salmon calcitonin and the amino terminus of the human calcitonin receptor. J Biol Chem 279: 6720-9 [PMID:14623894]

130. Piao FL, Cao C, Han JH, Kim SZ, Cho KW and Kim SH. (2004) Amylin-induced suppression of ANP secretion through receptors for CGRP1 and salmon calcitonin. Regul Pept 117: 159-166 [PMID:14749035]

131. Poyner DR, Sexton PM, Marshall I, Smith DM, Quirion R, Born W, Muff R, Fischer JA and Foord SM. (2002) International Union of Pharmacology. XXXII. The mammalian calcitonin gene-related peptides, adrenomedullin, amylin, and calcitonin receptors. Pharmacol Rev 54: 233-46 [PMID:12037140]

132. Purdue BW, Tilakaratne N and Sexton PM. (2002) Molecular pharmacology of the calcitonin receptor. Recept Channels 8: 243-55 [PMID:12529940]

133. Pérez Jurado LA, Li X and Francke U. (1995) The human calcitonin receptor gene (CALCR) at 7q21.3 is outside the deletion associated with the Williams syndrome. Cytogenet Cell Genet 70: 246-9 [PMID:7789182]

134. Qi T, Dong M, Watkins HA, Wootten D, Miller LJ and Hay DL. (2013) Receptor activity-modifying protein-dependent impairment of calcitonin receptor splice variant $\Delta(1-47) \mathrm{hCT}((\mathrm{a}))$ function. $\mathrm{Br}$ J Pharmacol 168: 644-57 [PMID:22946511]

135. Qing X and Keith IM. (2003) Targeted blocking of gene expression for CGRP receptors elevates pulmonary artery pressure in hypoxic rats. Am J Physiol Lung Cell Mol Physiol 285: L86-96 [PMID:12626334]

136. Quigley A, Pike ACW, Burgess-Brown N, Krojer T, Shrestha L, Goubin S, Kim J, Das S, Muniz JRC, Canning P, Chaikuad A, Vollmar M, Von Delft F, Arrowsmith CH, Weigelt J, Edwards AM, Bountra C, Barr AJ and Carpenter EP. Structure of the Extracellular Domain of Human Ramp2.

137. Roh J, Chang CL, Bhalla A, Klein C and Hsu SY. (2004) Intermedin is a calcitonin/calcitonin gene-related peptide family peptide acting through the calcitonin receptor-like receptor/receptor activity-modifying protein receptor complexes. J Biol Chem 279: 7264-74 [PMID:14615490]

138. Roth JD, Erickson MR, Chen S and Parkes DG. (2012) GLP-1R and amylin agonism in metabolic disease: complementary mechanisms and future opportunities. Br J Pharmacol 166: 121-36 [PMID:21671898]

139. Russell FA, King R, Smillie SJ, Kodji X and Brain SD. (2014) Calcitonin gene-related peptide: physiology and pathophysiology. Physiol Rev 94: 1099-142 [PMID:25287861]

140. Saetrum Opgaard O, Hasbak P, de Vries R, Saxena PR and Edvinsson L. (2000) Positive inotropy mediated via CGRP receptors in isolated human myocardial trabeculae. Eur J Pharmacol 397: 373-82 [PMID:10844137]

141. Salvatore CA, Hershey JC, Corcoran HA, Fay JF, Johnston VK, Moore EL, Mosser SD, Burgey CS, Paone DV and Shaw AW et al.. (2008) Pharmacological characterization of MK-0974 [N[(3R,6S)-6-(2,3-difluorophenyl)-2-oxo-1-(2,2,2-trifluoroethyl)azepan-3-yl]-4-(2-oxo-2,3-dihydro1H-imidazo[4,5-b]pyridin-1-yl)piperidine-1-carboxamide], a potent and orally active calcitonin gene-related peptide receptor antagonist for the treatment of migraine. J Pharmacol Exp Ther 324: 416-21 [PMID:18039958]

142. Schütz B, Mauer D, Salmon AM, Changeux JP and Zimmer A. (2004) Analysis of the cellular expression pattern of beta-CGRP in alpha-CGRP-deficient mice. J Comp Neurol 476: 32-43 [PMID:15236465]

143. Sexton PM, Houssami S, Hilton JM, O'Keeffe LM, Center RJ, Gillespie MT, Darcy P and Findlay DM. (1993) Identification of brain isoforms of the rat calcitonin receptor. Mol Endocrinol 7: 815- 


\section{1 [PMID:8395656]}

144. Sheward WJ, Lutz EM and Harmar AJ. (1994) The expression of the calcitonin receptor gene in the brain and pituitary gland of the rat. Neurosci Lett 181: 31-4 [PMID:7898764]

145. Shi L, Lehto SG, Zhu DX, Sun H, Zhang J, Smith BP, Immke DC, Wild KD and Xu C. (2016) Pharmacologic Characterization of AMG 334, a Potent and Selective Human Monoclonal Antibody against the Calcitonin Gene-Related Peptide Receptor. J Pharmacol Exp Ther 356: 22331 [PMID:26559125]

146. Shindo T, Kurihara Y, Nishimatsu H, Moriyama N, Kakoki M, Wang Y, Imai Y, Ebihara A, Kuwaki $\mathrm{T}$ and Ju KH et al.. (2001) Vascular abnormalities and elevated blood pressure in mice lacking adrenomedullin gene. Circulation 104: 1964-71 [PMID:11602502]

147. Smillie SJ and Brain SD. (2011) Calcitonin gene-related peptide (CGRP) and its role in hypertension. Neuropeptides 45: 93-104 [PMID:21269690]

148. Sonne N, Larsen AT, Andreassen KV, Karsdal MA and Henriksen K. (2020) The Dual Amylin and Calcitonin Receptor Agonist, KBP-066, Induces an Equally Potent Weight Loss Across a Broad Dose Range While Higher Doses May Further Improve Insulin Action. J Pharmacol Exp Ther 373: 92-102 [PMID:31992608]

149. Taboulet J, Frenkian M, Frendo JL, Feingold N, Jullienne A and de Vernejoul MC. (1998) Calcitonin receptor polymorphism is associated with a decreased fracture risk in postmenopausal women. Hum Mol Genet 7: 2129-33 [PMID:9817931]

150. Takei Y, Inoue K, Ogoshi M, Kawahara T, Bannai H and Miyano S. (2004) Identification of novel adrenomedullin in mammals: a potent cardiovascular and renal regulator. FEBS Lett 556: 53-8 [PMID:14706825]

151. Tam CW, Husmann K, Clark NC, Clark JE, Lazar Z, Ittner LM, Götz J, Douglas G, Grant AD and Sugden D et al.. (2006) Enhanced vascular responses to adrenomedullin in mice overexpressing receptor-activity-modifying protein 2. Circ Res 98: 262-70 [PMID:16373602]

152. Taylor GM, Meeran K, O'Shea D, Smith DM, Ghatei MA and Bloom SR. (1996) Adrenomedullin inhibits feeding in the rat by a mechanism involving calcitonin gene-related peptide receptors. Endocrinology 137: 3260-4 [PMID:8754748]

153. ter Haar E, Koth CM, Abdul-Manan N, Swenson L, Coll JT, Lippke JA, Lepre CA, Garcia-Guzman $\mathrm{M}$ and Moore JM. (2010) Crystal structure of the ectodomain complex of the CGRP receptor, a class-B GPCR, reveals the site of drug antagonism. Structure 18: 1083-93 [PMID:20826335]

154. Tilakaratne N, Christopoulos G, Zumpe ET, Foord SM and Sexton PM. (2000) Amylin receptor phenotypes derived from human calcitonin receptor/RAMP coexpression exhibit pharmacological differences dependent on receptor isoform and host cell environment. $J$ Pharmacol Exp Ther 294: 61-72 [PMID:10871296]

155. Tsujikawa K, Yayama K, Hayashi T, Matsushita H, Yamaguchi T, Shigeno T, Ogitani Y, Hirayama M, Kato T and Fukada S et al.. (2007) Hypertension and dysregulated proinflammatory cytokine production in receptor activity-modifying protein 1-deficient mice. Proc Natl Acad Sci USA 104: 16702-7 [PMID:17923674]

156. Uetake R, Sakurai T, Kamiyoshi A, Ichikawa-Shindo Y, Kawate H, Iesato Y, Yoshizawa T, Koyama T, Yang L and Toriyama Y et al.. (2014) Adrenomedullin-RAMP2 system suppresses ER stressinduced tubule cell death and is involved in kidney protection. PLOS ONE 9: e87667 [PMID:24505304]

157. Uezono Y, Nakamura E, Ueda Y, Shibuya I, Ueta Y, Yokoo H, Yanagita T, Toyohira Y, Kobayashi $\mathrm{H}$ and Yanagihara N et al.. (2001) Production of cAMP by adrenomedullin in human oligodendroglial cell line KG1C: comparison with calcitonin gene-related peptide and amylin. Brain Res Mol Brain Res 97: 59-69 [PMID:11744163]

158. Upton PD, Austin C, Taylor GM, Nandha KA, Clark AJ, Ghatei MA, Bloom SR and Smith DM. (1997) Expression of adrenomedullin (ADM) and its binding sites in the rat uterus: increased number of binding sites and ADM messenger ribonucleic acid in 20-day pregnant rats compared with nonpregnant rats. Endocrinology 138: 2508-14 [PMID:9165042]

159. Venkatanarayan A, Raulji P, Norton W, Chakravarti D, Coarfa C, Su X, Sandur SK, Ramirez MS, Lee J and Kingsley CV et al.. (2015) IAPP-driven metabolic reprogramming induces regression of p53-deficient tumours in vivo. Nature 517: 626-30 [PMID:25409149]

160. Villa I, Melzi R, Pagani F, Ravasi F, Rubinacci A and Guidobono F. (2000) Effects of calcitonin gene-related peptide and amylin on human osteoblast-like cells proliferation. Eur J Pharmacol 409: 273-278 [PMID:11108821]

161. Walker CS, Conner AC, Poyner DR and Hay DL. (2010) Regulation of signal transduction by calcitonin gene-related peptide receptors. Trends Pharmacol Sci 31: 476-83 [PMID:20633935]

162. Walker CS, Eftekhari S, Bower RL, Wilderman A, Insel PA, Edvinsson L, Waldvogel HJ, Jamaluddin MA, Russo AF and Hay DL. (2015) A second trigeminal CGRP receptor: function and expression of the AMY1 receptor. Ann Clin Transl Neurol 2: 595-608 [PMID:26125036]

163. Walker CS and Hay DL. (2013) CGRP in the trigeminovascular system: a role for CGRP, adrenomedullin and amylin receptors? Br J Pharmacol 170: 1293-307 [PMID:23425327]

164. Walker CS, Li X, Whiting L, Glyn-Jones S, Zhang S, Hickey AJ, Sewell MA, Ruggiero K, Phillips 
AR and Kraegen EW et al.. (2010) Mice lacking the neuropeptide alpha-calcitonin gene-related peptide are protected against diet-induced obesity. Endocrinology 151: 4257-69 [PMID:20610563]

165. Wang Z, Martorell BC, Wälchli T, Vogel O, Fischer J, Born W and Vogel J. (2015) Calcitonin gene-related peptide (CGRP) receptors are important to maintain cerebrovascular reactivity in chronic hypertension. PLoS ONE 10: e0123697 [PMID:25860809]

166. Warshawsky H, Goltzman D, Rouleau MF and Bergeron JJ. (1980) Direct in vivo demonstration by radioautography of specific binding sites for calcitonin in skeletal and renal tissues of the rat. J Cell Biol 85: 682-94 [PMID:7391137]

167. Wolfe 3rd LA, Fling ME, Xue Z, Armour S, Kerner SA, Way J, Rimele T and Cox RF. (2003) In vitro characterization of a human calcitonin receptor gene polymorphism. Mutat Res 522: 93105 [PMID:12517415]

168. Wunder F, Rebmann A, Geerts A and Kalthof B. (2008) Pharmacological and kinetic characterization of adrenomedullin 1 and calcitonin gene-related peptide 1 receptor reporter cell lines. Mol Pharmacol 73: 1235-43 [PMID:18174292]

169. Yamaguchi M. (1991) Stimulatory effect of calcitonin on Ca2+ inflow in isolated rat hepatocytes. Mol Cell Endocrinol 75: 65-70 [PMID:1646739]

170. Yamaguchi M, Watanabe Y, Ohtani T, Uezumi A, Mikami N, Nakamura M, Sato T, Ikawa M, Hoshino M and Tsuchida K et al.. (2015) Calcitonin Receptor Signaling Inhibits Muscle Stem Cells from Escaping the Quiescent State and the Niche. Cell Rep 13: 302-14 [PMID:26440893]

171. Yamauchi A, Sakurai T, Kamiyoshi A, Ichikawa-Shindo Y, Kawate H, Igarashi K, Toriyama Y, Tanaka M, Liu T and Xian X et al.. (2014) Functional differentiation of RAMP2 and RAMP3 in their regulation of the vascular system. J Mol Cell Cardiol 77: 73-85 [PMID:25264174]

172. Yamin M, Gorn AH, Flannery MR, Jenkins NA, Gilbert DJ, Copeland NG, Tapp DR, Krane SM and Goldring SR. (1994) Cloning and characterization of a mouse brain calcitonin receptor complementary deoxyribonucleic acid and mapping of the calcitonin receptor gene. Endocrinology 135: 2635-43 [PMID:7988453]

173. Yoshizawa T, Sakurai T, Kamiyoshi A, Ichikawa-Shindo Y, Kawate H, Iesato Y, Koyama T, Uetake R, Yang L and Yamauchi A et al.. (2013) Novel regulation of cardiac metabolism and homeostasis by the adrenomedullin-receptor activity-modifying protein 2 system. Hypertension 61: 341-51 [PMID:23297372]

174. Young AA, Gedulin B, Gaeta LS, Prickett KS, Beaumont K, Larson E and Rink TJ. (1994) Selective amylin antagonist suppresses rise in plasma lactate after intravenous glucose in the rat. Evidence for a metabolic role of endogenous amylin. FEBS Lett 343: 237-41 [PMID:8174707]

175. Young AA, Gedulin B, Vine W, Percy A and Rink TJ. (1995) Gastric emptying is accelerated in diabetic BB rats and is slowed by subcutaneous injections of amylin. Diabetologia 38: 642-8 [PMID:7672483]

176. Zhang Z, Liu X, Morgan DA, Kuburas A, Thedens DR, Russo AF and Rahmouni K. (2011) Neuronal receptor activity-modifying protein 1 promotes energy expenditure in mice. Diabetes 60: 1063-71 [PMID:21357463]

177. Zhang Z, Winborn CS, Marquez de Prado B and Russo AF. (2007) Sensitization of calcitonin gene-related peptide receptors by receptor activity-modifying protein-1 in the trigeminal ganglion. J Neurosci 27: 2693-703 [PMID:17344407]

178. Zimmermann U, Fluehmann B, Born W, Fischer JA and Muff R. (1997) Coexistence of novel amylin-binding sites with calcitonin receptors in human breast carcinoma MCF-7 cells. $J$ Endocrinol 155: 423-31 [PMID:9487987] 